J. Clin. Chem. Clin. Biochem.

Vol. 24, 1986, pp. 97-102

(C) 1986 Walter de Gruyter \& Co.

Berlin - New York

\title{
Evaluation of a Commercial Immunoenzymometric Assay Kit for Creatine Kinase MB Isoenzyme Determination Using Monoclonal Antibodies
}

\author{
By M. Panteghini, R. Bonora, F. Pagani and M. Calarco \\ 1st Laboratory of Clinical Pathology, Spedali Civili, Brescia, Italy
}

(Received July 9/October 25, 1985)

Summary: A simultaneous two-site immunoenzymometric assay for creatine kinase MB determination (Hybritech Tandem-E CK-MB) using monoclonal antibodies was evaluated and compared with cellulose acetate electrophoresis using fluorometric scanning densitometry.

The assay has satisfactory precision (between-day analysis gives a coefficient of variation between 2.1 and $9.4 \%)$ and is not susceptible to interference by concentrations of creatine kinase MM up to $5000 \mu \mathrm{g} / 1(3400$ $\mathrm{U} / \mathrm{l})$ and creatine kinase BB up to $1000 \mu \mathrm{g} / \mathrm{l}(1085 \mathrm{U} / \mathrm{l})$. The upper limit of MB isoenzyme concentration in 250 apparently healthy people was $5.5 \mu \mathrm{g} / \mathrm{l}$. Comparison between the immunoenzymometric assay (y) and electrophoresis $(x)$ yielded the following linear regression equation: $y=0.37 x+1.9$, with a correlation coefficient of 0.828 . The characteristics of the temporal kinetics of $\mathrm{MB}$ isoenzyme, calculated by two methods, in 49 patients with acute myocardial infarction, were nearly identical in terms of the rate of creatine kinase MB release and the time at which the peak value is obtained, but not in terms of the rate of elimination of the isoenzyme. The fractional disappearance rate of $\mathrm{MB}$ isoenzyme from the circulation was significantly higher if calculated with Tandem-E results rather than with electrophoresis results $(-0.035$ vs -0.028 , $\mathrm{p}<0.001)$. Whereas in the first day after infarction immunoenzymometric assay and electrophoresis had the same clinical sensitivity for identifying patients with acute myocardial infarction, in specimens collected more than 24 hours after the onset of the chest pain, the clinical sensitivity of the immunoenzymometric method was lower. Our results show that it is still premature to draw definitive clinical conclusions from the immunoassay results.

Evaluierung eines käuflichen immunenzymometrischen Testbestecks zur Bestimmung von Kreatinkinase MBIsoenzym mit monoklonalen Antikörpern

Zusammenfassung: Ein gleichzeitig auf zwei Teilkomponenten gerichteter enzymimmunometrischer Assay zur Bestimmung von Kreatinkinase MB mit monoklonalen Antikörpern (Hybritech Tandem-E CK-MB) wurde evaluiert und mit der Celluloseacetat-Elektrophorese mit fluorimetrischer Scanning-Densitometrie verglichen. Die Bèstimmung hat eine genügende Präzision (VK von Tag zu Tag 2,1-9,4\%) und wird durch Konzentrationen von Kreatinkinase MM bis zu $5000 \mu \mathrm{g} / \mathrm{l}(3400 \mathrm{U} / \mathrm{l})$ und von Kreatinkinase BB bis zu $1000 \mu \mathrm{g} / \mathrm{l}(1085$ U/1) nicht gestört. Die obere Grenze der Konzentration von Kreatinkinase MB bei 250 offenbar Gesunden war $5,5 \mu \mathrm{g} / 1$. Der Vergleich zwischen enzymometrischem Assay (y) und Elektrophorese (x) ergab die folgende Regressionsgleichung: $y=0,37 x+1,9$ mit einem Korrelationskoeffizienten von 0,828 .

Die Characteristika des zeitlichen Verlaufs der Konzentration von Isoenzym MB wurden bei 49 Patienten mit akutem Herzinfarkt nach zwei Methoden ermittelt. Sie waren bezüglich der Freisetzungsrate von Kreatinkinase MB und der Zeit, zu der der Spitzenwert erhalten wird, nahezu identisch, nicht jedoch bezüglich der Eliminationsrate des Isoenzyms. Die relative Schwundrate des Isoenzyms MB aus dem Kreislauf war bei 
Ermittlung aus den Tandem-E-Ergebnissen signifikant höher als die aus Elektrophoreseergebnissen ermittelte $(-0,035$ gegenüber $-0,028, \mathrm{p}<0,001)$. Während enzymimmunometrischer Assay und Elektrophorese am ersten Tag nach Infarkt die gleiche klinische Empfindlichkeit für die Identifizierung von Patienten mit akutem Myokardinfarkt aufwiesen, war die klinische Empfindlichkeit der enzymometrischen Methode geringer, wenn die Probenahme später als 24 Stunden nach Einsetzen des Brustschmerzes erfolgte. Unsere Ergebnisse zeigen, $\mathrm{da} B$ es noch verfrüht ist, endgültige klinische Schlüsse aus den Ergebnissen des Immunoassay zu ziehen.

\section{Introduction}

The enzyme creatine kinase (adenosine-5'-triphosphate: creatine N-phosphotransferase, EC 2.7.3.2) catalyses the reversible transfer of a phosphate group from adenosine-5'-triphosphate to creatine. It exists in the cytoplasm of the cells of human tissues as a dimer composed of two subunits, designated $M$ and $B$, having a relative molecular mass of 43000 and 44500 , respectively (1). These subunits combine to produce three dimeric molecular forms designated creatine kinase MM, MB and BB (2). A fourth isoenzyme, isolated from the mitochondria of mammalian tissues, has been shown to differ from the cytoplasmic forms in a number of biological and biochemical criteria (3-5). Concentrations (catalytic, mass) of creatine kinase $\mathrm{MB}$ in serum are used to determine whether cardiac damage has occurred: the low concentration of $\mathrm{MB}$ in normal serum and in tissues other than the heart is the basis of its use as a sensitive and relative specific indicator in the diagnosis of acute myocardial infarction (6-11). For these reasons, various techniques have been used to isolate and detect the MB isoenzyme. Three methods are at present in routine use: electrophoresis on cellulose acetate or agarose, anion-exchange chromatography and immunoinhibition, all having different analytical and clinical advantages and disadvantages $(12,13)$. Recently, a promising approach has been the use of anti-monomer $\mathrm{M}$ and anti-monomer $\mathrm{B}$ antibodies for specific detection of creatine kinase MB by "sandwich" techniques, with the determination of mass concentration of the enzyme instead of its catalytic activity concentration (14-18). The Tandem-E creatine kinase $\mathrm{MB}$ immunoenzymometric assay (Hybritech Inc., San Diego, CA 92121, USA) uses two monoclonal antibodies to determine the creatine kinase MB molecule; one monoclonal antibody is directed toward the $B$ subunit and the other toward the $\mathrm{M}$ subunit, producing an assay which is specific for creatine kinase MB (19).

In this report, we have evaluated the analytical performance of this new commercial kit and compared results with those obtained with an electrophoretic technique on acute myocardial infarction patients.

\section{Materials and Methods}

Blood samples

Fourty nine patients (43 men and 6 women, with ages ranging from 44 to 82 years), admitted to the Coronary Care Unit of the Civil Hospital of Brescia because of acute myocardial infarction, were studied. Myocardial necrosis assessment was based on usual diagnostic criteria (20). Peripheral venous blood samples were obtained immediately after admission to the hospital, every 4 hours for the first 24 hours and every 8 hours for the following 48 hours.

In addition, 250 healthy people (125 women and 125 men, whose ages ranged from 10 to 70 years), with normal serum biochemical and haematological tests and without clinical evidence of cardiac and muscle diseases, were studied in order to establish the reference level of creatine kinase MB isoenzyme concentration in serum.

All serum samples were assayed immediately for total creatine kinase activity; electrophoresis and enzyme immunoassay were performed within 24 hours after collection with interim storage at $-20^{\circ} \mathrm{C}$ in hermetically sealed plastic containers.

Assay methods

Measurement of total creatine kinase

Total creatine kinase activity was measured with the standard method of the Scandinavian Committè on Enzymes (21) with reagents from Boehringer, Mannheim, FRG, on a Cobas Bio centrifugal analyzer (F. Hoffmann La Roche and Co., Ltd., Basle, Switzerland). Catalytic activity was expressed in terms of $U / 1$ serum (1 Unit $=1 \mu \mathrm{mol}$ substrate converted per minute under optimal conditions) measured at $37^{\circ} \mathrm{C}$; discrimination limits were $160 \mathrm{U} / 1$ for women and $190 \mathrm{U} / 1$ for men.

\section{Electrophoresis}

We electrophoretically separated creatine kinase isoenzymes on Titan III cellulose acetate membrane by using the Zip Zone electrophoresis chamber (Helena Laboratories, Beaumont, TX 77704, USA) and creatine kinase reagents from Boehringer. Isoenzymes were separated according to the manufacturer's instruction; after incubation for 25 minutes at $37^{\circ} \mathrm{C}$, the isoenzyme bands were visible by virtue of their fluorescence and quantitated by fluorometric scanning of the tracings with a Helena Cliniscan densitometer; the ratio of isoenzymes was calculated from the integrated area under each peak and the enzymic activity of the MB band was calculated from the product of the total creatine kinase activity and the percentage of the fluorescence appearing in the $\mathrm{MB}$ region. The method is linear to $500 \mathrm{U} / 1$ per band. Samples with values greater than this should be diluted with saline. Using this method, creatine kinase $\mathrm{MB}$ is undetectable in serum from healthy subjects. 


\section{Enzyme immunoassay}

The kit assay (product no. $R$ 4993) was performed according to the manufacturer's direction insert. This assay is a solid phase two-site immunoenzymometric method. Sample containing creatine kinase MB is reacted with a plastic bead, which is coated with a monoclonal antibody directed toward $M$ subunit of the creatine kinase MB molecule, and with a bovine alkaline phosphatase-conjugated monoclonal antibody directed against an antigenic site on the $B$ subunit of the same creatine kinase MB molecule. Unbound conjugate is removed by washing. A chromogenic substrate is added and the amount of its turnover is determined colorimetrically; the creatine kinase MB concentration present in the sample is directly proportional to the colour intensity. Results quantified by comparing sample response with that of creatine kinase MB calibrator (lyophilized human scrum containing purified human creatine kinase $M B$ ) of known concentration, are reported in micrograms per litre.

The assay procedure is as follows. Place a single antibodycoated bead into each $12 \times 75 \mathrm{~mm}$ plastic test tube. Add 100 $\mu \mathrm{l}$ of antibody conjugate and $100 \mu \mathrm{l}$ of zero diluent (human serum containing no detectable concentration of creatine kinase MB) or calibrator or serum sample (in duplicate). Shake the assay tubes to ensure mixing and incubate the lubes for two hours on a horizontal rotator set, at room temperature. Add $2 \mathrm{ml}$ of wash solution (composition not available from manufacturer) to each tube, aspirate the liquid and repeat this wash step twice. Add $200 \mu \mathrm{l}$ of substrate reagent (p-nitrophenylphosphate) to each tube and incubate for 30 minutes at room temperature. The reaction is stopped with $1.5 \mathrm{ml}$ of quench reagent, containing ethylenediaminetetraacetic acid, and the samples are read in a spectrophotometer at $405 \mathrm{~nm}$; in our laboratory a LKB 7400 calculating absorptiometer (LKB Produckter AB, Bromma, Sweden) was used which automatically calculates the net absorbance for the calibrator or specimens by subtracting the absorbance of zero diluent.

\section{Characterization of human creatine kinase $M M$ and $B B$ isoen- zymes}

The purified MM and BB isoenzymes of creatine kinase, employed for specificity studies, were obtained from CalbiochemBehring Diagnostics, La Jolla, CA 92037, USA. Creatine kinase MM (product no. 238407) was purified from human skeletal muscle and creatine kinase BB (product no. 238397) was purified from human brain; the purity of each isoenzyme preparation was determined by electrophoresis on polyacrylamide gel. The specific activity of each purified isoenzyme was calculated from the total creatine kinase activity measured at $37^{\circ} \mathrm{C}$ (see above); total protein concentration was measured by the procedure of Lowry et al. (22). Final preparations of the BB and MM isoenzymes were electrophoretically homogeneous and had specific activities of about $1080 \mathrm{U}$ and $685 \mathrm{U} / \mathrm{mg}$ protein, respectively.

\section{Statistical analysis}

Calculations of mean, standard deviation, coefficient of variation, correlation coefficient and linear regression analysis were carried out by standard methods (23). Since values for the serum enzymes were not normally distributed, the statistical analyses were performed with non-parametric statistical tests, with use of the Wilcoxon test for paired observations (23). The clearance rates (Kd) for each isoenzyme were calculated from the declining slopes of the time-activity curves by linear regression analysis, using a logarithmic scale for enzyme activities (log-scale $y$-axis) against the time elapsed since the onset (time zero) of the characteristic pain of myocardial infarct (x-axis) (24).

Significance was established at the level of $p<0.05$.

\section{Results}

Time course of "sandwich" formation

The effect of varying the duration of the first incubation is illustrated in figure 1. Evidently, "sandwich" formation is complete within the two hours incubation recommended by the supplier.

A possible advantage of the Tandem-E type of assay is that, since antibody conjugate is added in excess, small pipetting errors in dispensing it may not be significant. In fact, under experimental conditions, the assay response is constant for volumes of antibody conjugate ranging between 80 and $120 \mu \mathrm{l}$.

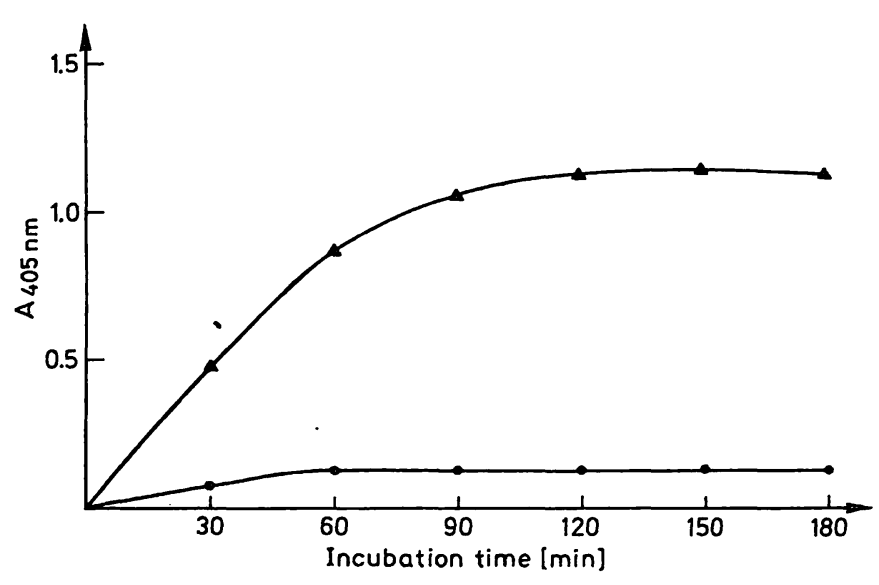

Fig. 1. Time course of "sandwich" formation with the Tandem$\mathrm{E}$ assay for creatine kinase MB.

Standards of $15(\mathbf{0}-\mathbf{0})$ and $80(\boldsymbol{\Delta}-\mathbf{\Delta}) \mu \mathrm{g} / 1$ were supplied with the kit. Abscissa: duration of incubation of the antibody-coated bead with serum specimen and enzyme-conjugated antibody. Ordinate: absorbance reading after 30 minute incubation with $p$-nitrophenylphosphate solution.

\section{Detection limit}

We assessed technical sensitivity by 10 replicate measurements of the zero diluent supplied with the kit. The mean final absorbance was $0.077 \mathrm{~A}$ (standard deviation, $0.010 \mathrm{~A}$ ). The calibrator indicated $0.721 \mathrm{~A}$ per $61 \mu \mathrm{g} / \mathrm{l}$. The minimal detectable concentration of creatine kinase $\mathrm{MB}$, defined as that amount giving a signal exceeding the mean zero signal by three standard deviations, was $2.5 \mu \mathrm{g} / \mathrm{l}$.

\section{Linearity and dose/response curve}

In the standard assay procedure, creatine kinase $\mathrm{MB}$ values up to $120 \mu \mathrm{g} / \mathrm{l}$ generate a linear absorbance signal. A strongly positive creatine kinase MB serum was serially diluted with zero diluent; for this specimen, the results were $120,100,50,25,12.5,6.3$ and $3.1 \mu \mathrm{g} / 1$ and final absorbance readings were respect- 
ively $1.405,1.225,0.565,0.303,0.120,0.061$ and 0.021 . This response is highly linear (correlation coefficient, 0.9993; standard error of estimation, 0.024).

\section{Precision}

Precision studies are shown in table 1 . Within-run precision was determined by twenty replicate determinations of three different serum samples in one assay; between-day precision was determined by ten measurements of three different serum samples over a series of individually calibrated runs. The coefficients of variation for intra- and inter-assay precision were between 1.8 and $9.4 \%$.

\section{Interference studies}

Haemoglobin (up to $2.5 \mathrm{~g} / \mathrm{l}$ ), bilirubin (up to 430 $\mu \mathrm{mol} / \mathrm{l}$ ), triglycerides (up to $11 \mathrm{mmol} / \mathrm{l}$ ), albumin (up to $150 \mathrm{~g} / \mathrm{l}$ ) and adenylate kinase (up to $2.5 \mathrm{~g} / \mathrm{l}$ ) do not interfere with the evaluated method.

To confirm the MB isoenzyme specificity of the Tandem-E procedure, we tested the effect of purified human creatine kinase $\mathrm{MM}$ and $\mathrm{BB}$ on assay. The results obtained are presented in table 2 . Addition of concentrations of creatine kinase $\mathrm{MM}$ lower than $5000 \mu \mathrm{g} / 1(3400 \mathrm{U} / \mathrm{l})$ and of creatine kinase BB lower than $1000 \mu \mathrm{g} / \mathrm{l}(1080 \mathrm{U} / \mathrm{l})$ to serum sample containing a known concentration of $\mathrm{MB}$ isoenzyme did not alter the assayed response of creatine kinase $\mathrm{MB}$ from this serum sample.

Tab. 1. Precision of creatine kinase MB isoenzyme determination by the evaluated method.

\begin{tabular}{rlllll}
\hline \multicolumn{2}{c}{ Within-run $(\mathrm{n}=20)$} & \multicolumn{3}{c}{ Between-day $(\mathrm{n}=10)$} \\
$\mathrm{x}$ & $\mathrm{SD}$ & $\mathrm{CV}$ & \multicolumn{2}{l}{$\mathrm{x}$} & \multicolumn{2}{l}{$\mathrm{SD}$} & $\mathrm{CV}$ \\
$(\mu \mathrm{g} / \mathrm{l})$ & $(\mu \mathrm{g} / \mathrm{l})$ & $(\%)$ & $(\mu \mathrm{g} / \mathrm{l})$ & $(\mu \mathrm{g} / \mathrm{l})$ & $(\%)$ \\
\hline 5.5 & 0.27 & 4.9 & 6.5 & 0.61 & 9.4 \\
29.8 & 0.95 & 3.2 & 25.1 & 1.03 & 4.1 \\
43.6 & 0.79 & 1.8 & 41.0 & 0.85 & 2.1 \\
\hline
\end{tabular}

All runs performed with a single lot number of reagent kits.

Tab. 2. Influence of creatine kinase $M M$ and $B B$ on the immunoenzymometric determination of $\mathrm{MB}$ isoenzyme.

\begin{tabular}{rcrll}
\hline $\mathrm{MM}$ & MB & BB & $\begin{array}{l}\text { MB } \\
\text { found }\end{array}$ & $\begin{array}{l}\text { Percentage } \\
\text { of decrease } \\
\text { in MB } \\
\text { concentration }\end{array}$ \\
\hline$(\mu \mathrm{g} / \mathrm{l})$ & $(\mu \mathrm{g} / \mathrm{l})$ & $(\mu \mathrm{g} / \mathrm{l})$ & $(\mu \mathrm{g} / \mathrm{l})$ & - \\
10000 & 0 & 0 & Undetectable & - \\
0 & 0 & 10000 & Undetectable & - \\
2500 & 41.0 & 0 & 42.2 & - \\
5000 & 41.0 & 0 & 36.9 & $10 \%$ \\
0 & 41.0 & 500 & 40.6 & $1 \%$ \\
0 & 41.0 & 1000 & 36.5 & $11 \%$ \\
\hline
\end{tabular}

\section{Comparison among the methods}

The results of the analytical comparison among the immunoenzymometric assay $(\mu \mathrm{g} / \mathrm{l})$ and electrophoresis $(\mathrm{U} / \mathrm{l})$ for 120 individual samples submitted at random to our clinical laboratory from the Department of Cardiology of our hospital' are shown in figure 2. The data show considerable scatter; in particular, at low MB values, the ratio electrophoresis/ immunoenzymometric assay is systematically higher.

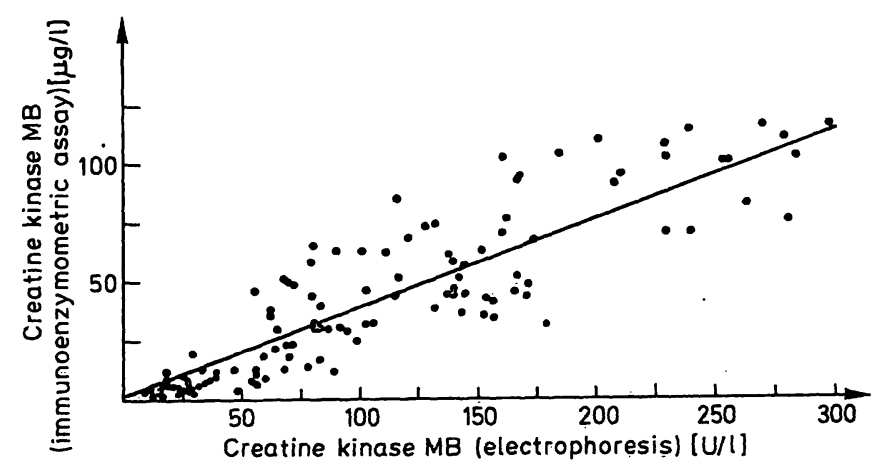

Fig. 2. Correlation of results for creatine kinase MB by electrophoresis ( $x$-axis) with those by immunoenzymometric assay ( $\mathrm{y}$-axis). Linear regression analysis yields a regression equation of $y=0.37 x+1.9$ (solid line) with a coefficient of correlation of 0.828 and a standard error of the estimate of 19.3. Number of patient samples is 120 .

\section{Reference interval}

The concentration of $\mathrm{MB}$ isoenzyme in sera from 250 apparently healthy subjects was measured by the immunoenzymometric method and the reference interval calculated by employing non-parametric determination of percentiles. The upper limit of reference values, defined as 95th percentile, was $5.5 \mu \mathrm{g} / \mathrm{l}$; this upper limit was the cut-off value used to define an above-normal concentration of $\mathrm{MB}$ isoenzyme in the analysis of clinical specimens. Again, there was no sex-related difference.

Comparison studies in patients with acute myocardial infarction

Table 3 summarizes the data base of clinical cases and the results of isoenzyme measurements by immunoenzymometric assay and electrophoresis on the 49 patients with acute myocardial infarction. The results, obtained with both analytical methods, were significantly correlated but there were discordant results. At 10 hours after myocardial necrosis, two patients with detectable MB band at electrophoresis had MB isoenzyme concentrations of less than $5.5 \mu \mathrm{g} / 1(2.0$ and $3.3 \mu \mathrm{g} / 1$, respectively). All specimens collected between 16 and 24 hours after the onset of the clinical symptoms had abnormal isoenzyme results by both analytical methods; moreover, the.immunoenzymo- 
Tab. 3. Summary of results of isoenzyme tests (median value and range) in the course of acute myocardial infarction (49 patients).

\begin{tabular}{|c|c|c|c|c|}
\hline $\begin{array}{l}\text { Hours } \\
\text { after } \\
\text { onset } \\
\text { of } \\
\text { chest } \\
\text { pain }\end{array}$ & $\begin{array}{l}\text { Total } \\
\text { creatine } \\
\text { kinase } \\
\text { catalytic } \\
\text { concen- } \\
\text { tration } \\
(\mathrm{U} / 1)\end{array}$ & $\begin{array}{l}\text { MB } \\
\text { isoenzyme } \\
\text { catalytic } \\
\text { concen- } \\
\text { tration } \\
(\mathrm{U} / \mathrm{l})\end{array}$ & $\begin{array}{l}\text { MB } \\
\text { isoenzyme } \\
\text { mass } \\
\text { concen- } \\
\text { tration }\end{array}$ & $\begin{array}{l}\text { Corre- } \\
\text { lation } \\
\text { of } \mathrm{MB} \\
\text { catalytic } \\
\text { and } \mathrm{MB} \\
\text { mass } \\
\text { concen- } \\
\text { tration }\end{array}$ \\
\hline 4 & $\begin{array}{l}157 \\
(45-231)\end{array}$ & $\begin{array}{l}4.5 \\
(0-24)\end{array}$ & $\begin{array}{l}6.1 \\
(0-25.2)\end{array}$ & $\begin{array}{l}r=0.836 \\
p<0.001\end{array}$ \\
\hline 10 & $\begin{array}{l}735 \\
(290-2075)\end{array}$ & $\begin{array}{l}153 \\
(27-581)\end{array}$ & $\begin{array}{l}65.9 \\
(2.0-236.0)\end{array}$ & $\begin{array}{l}r=0.749 \\
p<0.001\end{array}$ \\
\hline 16 & $\begin{array}{l}1103 \\
(366-3563)\end{array}$ & $\begin{array}{l}238 \\
(39-788)\end{array}$ & $\begin{array}{l}110.6 \\
(12.5-294.2)\end{array}$ & $\begin{array}{l}r=0.640 \\
p<0.001\end{array}$ \\
\hline 24 & $\begin{array}{l}1264 \\
(214-6360)\end{array}$ & $\begin{array}{l}265 \\
(23-1081)\end{array}$ & $\begin{array}{l}94.0 \\
(5.6-361.2)\end{array}$ & $\begin{array}{l}r=0.661 \\
p<0.001\end{array}$ \\
\hline 48 & $\begin{array}{l}717 \\
(110-3865)\end{array}$ & $\begin{array}{l}59 \\
(0-396)\end{array}$ & $\begin{array}{l}14.5 \\
(0-74.3)\end{array}$ & $\begin{array}{l}r=0.684 \\
p<0.001\end{array}$ \\
\hline 72 & $\begin{array}{l}244 \\
(50-1493)\end{array}$ & $\begin{array}{l}8.5 \\
(0-89)\end{array}$ & $\begin{array}{l}2.5 \\
(0-11.6)\end{array}$ & $\begin{array}{l}r=0.605 \\
p<0.001\end{array}$ \\
\hline
\end{tabular}

metric assay did not identify myocardial infarct patients earlier than electrophoresis (the sensitivity at 4 hours after the onset of chest pain was the same, $66 \%$ of abnormal test results for both methods).

The data for isoenzyme kinetics in acute myocardial infarction are presented in table 4. Peak times did not differ significantly according to methodology and the peak activity value of MB isoenzyme by electrophoresis correlates significantly with the peak concentration of $\mathrm{MB}$ as measured by immunoenzymometric assay. On the contrary, the fractional disappearance rates of the MB isoenzyme from the circulation were statistically different if calculated with the results obtained with the two methodologies employed. In confirmation of this, abnormal mass concentration of MB isoenzyme in specimens collected at 72 hours after the onset of chest pain were observed only in the $14 \%$ of cases of infarction against $57 \%$ of cases with abnormal enzymatic activity.

\section{Discussion}

The objective of this study was to determine whether the Tandem-E assay with monoclonal antibodies could be used to replace the traditional electrophoretic technique for measuring creatine kinase $\mathrm{MB}$ in the diagnosis of myocardial infarction.

The analytical data demonstrate that the immunoenzymometric assay is a reliable method for quantification of serum creatine kinase MB. This assay has satisfactory precision for clinical application and adequate sensitivity for detecting MB levels encountered in normal sera. Our precision studies indicate that the method performs much better than indicated by Shehan \& Haythorn (25). On the other hand, in our initial experience with this kit, we occasionally obtained discrepant duplicate measurements: particular attention to the washing steps in the procedure, each with vigorous decanting, has decreased this problem of spurious high readings, probably due to unbound phosphatase activity. Analytical specificity is high: the failure of pathological values of the $\mathrm{BB}$ and $\mathrm{MM}$ isoenzymes to react in the assay suggests that no spurious high levels should be obtained for interference phenomena. Advantages of this procedure are that no special equipment is needed other than a colorimeter and a single point calibration suffices to obtain a linear calibration curve for quantitation of results. Monoclonal antibodies provide two required criteria for linear immunological reaction: homogeneous reactivity and excess reagent (26); the third requirement is the linear production of a measurable response by the enzyme-label system, which is alkaline phosphatase. The main disadvantage is that the immunoenzymometric method is more time-consuming than conventional electrophoresis. We found that turnaround times for results from the Tandem procedure were approximately double those for the electrophoresis (about 3 hours for results by the former vs 1.5 hours for the latter). Therefore, even the evaluated enzyme immunoassay, like other methodologies, cannot be performed 24 hours a day or during weekends

Tab. 4. Data for isoenzyme kinetics (median value and range) in 49 acute myocardial infarction patients.

\begin{tabular}{|c|c|c|c|c|}
\hline & $\begin{array}{l}\text { MB } \\
\text { isoenzyme catalytic } \\
\text { concentration }\end{array}$ & $\begin{array}{l}\text { MB } \\
\text { isoenzyme } \\
\text { mass concentration }\end{array}$ & $\begin{array}{l}\text { Significance } \\
\text { of difference }\end{array}$ & Correlation \\
\hline Peak time (hours) & $\begin{array}{l}20.5 \\
(9.4 / 28.0)\end{array}$ & $\begin{array}{l}19.3 \\
(10.6 / 28.2)\end{array}$ & NS & $\begin{array}{l}r=0.614 \\
p<0.001\end{array}$ \\
\hline Peak value & $\begin{array}{l}320.9 \mathrm{U} / 1 \\
(39 / 1097)\end{array}$ & $\begin{array}{l}130.4 \mu \mathrm{g} / 1 \\
(12.5 / 353)\end{array}$ & & $\begin{array}{l}r=0.605 \\
p<0.001\end{array}$ \\
\hline $\begin{array}{l}\text { Fractional disappearance rate } \\
\text { per hour }\end{array}$ & $\begin{array}{l}-0.028 \\
(-0.011 /-0.050)\end{array}$ & $\begin{array}{l}-0.035 \\
(-0.010 /-0.056)\end{array}$ & $p<0.001$ & \\
\hline
\end{tabular}

NS, not significant 
and holidays in a stat lab. Moreover, potential drawbacks are that falsely positive reactions may result from the presence of heterophilic antibodies in tested serum (27) and falsely negative results may be seen in patients with endogenous anti-B autoantibodies (28).

Our clinical evaluation was planned to emphasize the agreement and disagreement in results of the two MB assays (immunoenzymometric and electrophoretic) rather than their specificity and sensitivity for the diagnosis of myocardial infarction. The clinical findings demonstrate that, for most studied patients, the early temporal sequence of $\mathrm{MB}$ isoenzyme after infarction was the same by both methods. In particular, we were not able to demonstrate MB in the blood after myocardial infarction earlier by Tandem-E assay than by electrophoresis. Results were nearly identical in terms of the rate of creatine kinase MB release and the time at which the peak value is obtained but not in terms of the rate of elimination of the isoenzyme. The fractional disappearance rate of $\mathrm{MB}$ isoenzyme from the circulation was significantly higher if calculated with Tandem-E results rather than with electrophoresis results and, as a result of this, the ratio electrophoresis/immunoenzymometric assay seemed to increase during the post-infarction period.

\section{References}

1. Perryman, M. B., Strauss, A. W., Buettner, T. L. \& Roberts, R. (1983) Biochim. Biophys. Acta 747, 284-290.

2. Lang, H. \& Würzburg, U. (1982) Clin. Chem. 28, 1439-1447.

3. Wevers, R. A., Mul-Steinbusch, M. W. F. J. \& Soons, J. B. J. (1980) Clin. Chim. Acta 101, 103-111.

4. Wevers, R. A., Reutelingsperger, C. P. M., Dam, B. \& Soons, J. B. J. (1982) Clin. Chim. Acta 119, 209-223.

5. Kanemitsu, F., Kawanishi, I. \& Mizushima, J. (1982) Clin. Chim. Acta 119, 307-317.

6. Irvin, R. G., Cobb, F. R. \& Roe, C. R. (1980) Arch. Intern. Med. 140, 329-334.

7. Lott, J. A. \& Stang, J. M. (1980) Clin. Chem. 26, $1241-1250$.

8. Gerhardt, W., Waldenström, J., Hörder, M., Hofvendahl, S., Billström, R., Ljungdahl, R., Berning, H. \& Bagger, P. (1982) Clin. Chem. 28, 277-283.

9. Werner, M., Brooks, S. H., Mohrbacher, R. J. \& Wassermann, A. G. (1982) Clin. Chem. 28, 1297-1302.

10. Van Steirteghem, A. C., Zweig, M. H., Robertson, E. A. Bernard, R. M., Putzeys, G. A. \& Bieva, C. J. (1982) Clin. Chem. 28, 1319-1324.

11. Fisher, M. L., Carliner, N. H., Becker, L. C., Peters, R. W. \& Plotnick, G. D. (1983) J. Am. Med. Assoc. 249, 393-394

12. Morin, L. G. (1977) Clin. Chem. 23, 205-210.

13. Seckinger, D. L., Vazquez, D. A., Rosenthal, P. K. \& Mendizabal, R. C. (1983) Am. J. Clin. Pathol. 80, 164-169.

14. Willson, V. J. C., Jones, H. M. \& Thompson, R. J. (1981) Clin. Chim. Acta 113, 153-163.

15. Usategui-Gomez, M., Wicks, R. V., Farrenkopf, B., Hager, H. \& Warshaw, M. (1981) Clin. Chem. 27, 823-827.

16. Kwong, T. C., Rothbard, R. L. \& Biddle, T. L. (1981) Clin. Chem. 27, 828-831.

17. Jackson, A. P., Siddle, K. \& Thompson, R. J. (1984) Clin. Chem. 30, 1157-1162.
Therefore, in the first day after infarction, test results by immunoenzymometric assay and electrophoresis had the same diagnostic sensitivity for identifying patients with acute myocardial necrosis, whereas in specimens collected more than 24 hours after the onset of chest pain, abnormal MB isoenzyme results were detected less frequently by the Tandem- $E$ method rather than by electrophoresis. The reason for this is not clear; one explanation for these findings is that the evaluated assay could recognize merely protein epitopes dissociated untimely from cellular native MB molecule in the peripheric circulation. Certainly, the use of an immunological assay employing monoclonal antibodies may supply new biochemical and clinical information. The monoclonal antibodies, in deed, represent a defined homogeneous reagent in terms of epitopes, affinity and reactivity, which supplies new perspectives for the standardization and for the application of immunological determinations of different molecular forms of the enzymes (29). On the other hand, in partial contrast with other reports $(30,31)$, our results show that it is dangerous to draw definitive conclusions from the immunoassay results, as an exact comparison between enzyme activity and mass concentration measurements appears not to be possible.

18. Fenton, J. J., Brunștetter; S., Gordon, W. C., Rippe, D. F. \& Bell, M. L. (1984) Clin. Chem. 30, 1399-1401.

19. Myrtle, J. A., Shimizu, I., Varga, M., Kotler, H. \& Bartholomew, R. M. (1983) Clin. Chem. 29, 1232-1233.

20. Report of the joint International Society and Federation of Cardiology/World Health Organization Task Force on Standardization of Clinical Nomenclature (1979) Circulation 59, 607-609.

21. The Committèe on Enzymes of the Scandinavian Society for Clinical Chemistry and Clinical Physiology (1979) Scand. J. Clin. Lab. Invest. 39, 1-5.

22. Lowry, O. H., Rosebrough, N. J., Farr, A. L. \& Randall, R. J. (1951) J. Biol. Chem. 193, 265-275.

23. Armitage, P. (1971) Statistical methods in medical research. Wiley, New York.

24. Norris, R. M., Whitlock, R. M. L., Barratt-Boyes, C. \& Small, C. W. (1975) Circulation 51, 614-620.

25. Sheehan, M. \& Haythorn, P. (1985) Clin. Chem. 31, $160-161$.

26. Falkenberg, F. W., Pierard, D., Mai, U. \& Kantwerk, G. (1984) J. Clin. Chem. Clin. Biochem. 22, 867-882.

27. Bock, J. L., Furgiuele, J. \& Wenz, B. (1985) Clin. Chim. Acta $147,241-246$.

28. Stein, W. \& Bohner, J. (1985) Clin. Chem. 31, 1189-1192.

29. Bohner, J. \& Stein, W. (1984) J. Clin. Chem. Clin. Biochem. $22,943-952$.

30. Chan, D. W., Taylor, E., Frye, R. \& Blitzer, R. L. (1985) Clin. Chem. 31, 465-469.

31. Wu, A. H. B., Gornet, T. G., Bretaudiere, J.P. \& Panfili, P. R. (1985) Clin. Chem. 31, 470-474.

Dr. Mauro Panteghini

1st Laboratory of Clinical Pathology

Spedali Civili

I-25100 Brescia 